\title{
The Role of Non-Governmental Organizations in Community Economic Development: Using a System Dynamic Approach
}

\author{
Ejiro U. Osiobe (Corresponding author) \\ Department of Economics, Applied Statistics, and International Business, New Mexico State University, MSC 3CQ P. O. \\ BOX 30001, Las Cruces, NM 88003-8001, USA. \\ Tel: +1 (575) 646 - 1682 E-mail: euosiobe@nmsu.edu or jiji@aneosiobe.ngo \\ Stephen A. Osiobe \\ Edwin Clark University, Kiagbodo, Delta State, Nigeria. \\ Tel: +234 8035909019 E-mail: dr.o@aneosiobe.ngo
}

Peters A. Olushola

Ane Osiobe International Foundation, Plot 114 Lugbe, Federal Capital Territory NG, 900001, Nigeria

Tel: +234 8035909019 E-mail: fnd.rep@aneosiobe.ngo

This research is financed by Ane Osiobe International Foundation CAC No. 83828 TCC No. 10484010

Web: www.aneosiobe.ngo

\begin{abstract}
Non-governmental organizations (NGOs) are essential institutional players in mobilizing regional economic growth and development, community growth and development, motivating people, and implementing social welfare program(s) to support government effort(s) at the grassroots level. This paper explores the impact of NGOs on rural community development while referencing the case study of the community of Lugbe, in the city Abuja, Federal Capital Territory (FCT), Nigeria. This paper utilizes the NGO-Donation-system dynamics model $\left(N G O_{D}-D E M\right)$, to explore, visualize, and analyze the following dilemmas of NGOs donations responsiveness to Nigeria's per capita income, returns on foreign capital, and the returns on local capital. It analyzes two sensitivity scenarios from the base $N G O_{D}-D E M$ (see Figure 1). The findings show how NGOs activities result in fostering economic growth and development in the community. Our results show that if Local Returns on Capital $\left(L_{R K}\right)$ are greater than Foreign Returns on Capital $\left(R_{F I}\right)$, there will be a higher inflow of Foreign Direct Investment (FDI) into the nation and vice versa. Hence, if the later statement holds to be true, the cost-effectiveness for individuals and businesses to donate or invest in the country will decrease (see Figure 3 ). But, if the former statement is true, there will be zero donations into NGOs as long as individual per capita income is below the Income Threshold to Donate $\left(Y_{\text {donate }}\right)$ and companies make zero economic profits in their businesses. The $Y_{\text {donate }}$ is between $\$ 0-\$ 13,000$. But, when the individual per capita income or a business net economic profit is between $\$ 14,000-\$ 80,000$, which is above $Y_{\text {donate }}$, donations and investments will increase until the point when it peaks and starts to decrease (see Figure 4). Further result(s) show that the involvement of NGOs in societies where citizens are underserved by the financial, educational, entrepreneurial, political, and health industries have a normal distribution relationship shaped curve for the labor force per capita income threshold, an inverse relationship on returns on $L_{R K}$, and a positive returns on $R_{F I}$. The participation of NGOs in communities, ceteris paribus, has had a significant positive effect on the Nigerian economy, but the research does not overlook mistakes made by these NGOs in trying to solve wicked problems in an economy.
\end{abstract}

Keywords: community, development, NGOs, Local Returns on Capital $\left(L_{R K}\right)$, Foreign Returns on Capital $\left(R_{F I}\right)$, Foreign, Direct Investment $(F D I)$, and Income threshold to donate $\left(Y_{\text {donation }}\right)$.

DOI: $10.7176 / \mathrm{JESD} / 10-20-01$

Publication date:October $31^{\text {st }} 2019$

\section{Introduction:}

Emerging markets, as they try to restructure their communities, and social services have become paramount with the full participation of its members (United Nations Department of Economic and Social Affairs, 2008). Economic community development is the process by which people partner with their government to improve the economic, social, political, and cultural welfare of their society (United Nation (UN), 1956). This phenomenon can be categorized as trying to solve a wicked problem in a community. A wicked problem is a complicated and challenging social issue that requires analysis in order to address changing dynamics and blind spots. In general, wicked problems usually involve an interdisciplinary approach in order to be resolved. The UN's definition of economic community development posits that the people in a community must utilize their political, built, cultural, and financial capital with the government (public sector - private sector - NGOs) in a partnership to foster long-term sustainable economic growth and development.

The altruistic desire for people to participate in community growth and development in Nigeria led to the establishment of the NGO industry. In 1945, the term NGO came into use because of the need for the UN to differentiate between participation rights for specialized intergovernmental agencies and those for international private organizations. These 
international private organizations are called civil society organizations, citizens associations, and private voluntary organizations. Today, they are called NGOs. The UN employs the use of this term to differentiate between representatives of these agencies from those of governments (Ime, 2014).

The establishment of NGOs in Nigeria dates to the pre-independence period (Elumilade et al., 2006). However, it was when the successive post-colonial government found it difficult to cope with managing the developmental needs of Nigerians that people began to see the importance and impacts of NGOs to the public. An NGO is a company that has the following characteristics:

- $\quad$ They are not created to generate personal profit: Although they may engage in revenue-generating businesses, these profits are distributed to the public per their goals and objectives.

- $\quad$ They are voluntary: This means that they are formed voluntarily and that there is usually an element of voluntary participation in the organization.

- $\quad$ They are subject to their fiduciary duty: They are accountable to their members, donors, and stakeholders under the fiduciary law.

- They are independent of the government and other public authorities and political parties or commercial organizations. The independence of NGOs is very crucial to their operations because this empowers them to play supervisory and advocacy roles effectively. Their autonomy from government, political parties, and religious institutions position them to earn the public trust. This characteristic makes NGOs highly reputable and very influential.

\section{Literature Review:}

The stoic belief that people can work together to shape their destiny when allowed to participate in a free, open, and non-threatening environment is what formed the basis of community development. Community development has been one of the most significant social forces in the process of planned and effective change. A community is a recognized social unit, such as a group or association of individuals with a common need, value, interest, and function.

Community growth, development, and stability can be viewed as a continuous process, through which stakeholders of a community come together to take collective actions and generate solutions to their everyday problems. Community development can range from a small initiative within a small group of people to greater actions that involve a broader environment. The concept of community development has evolved over the years from the primitive period, pre-industrial, post-industrial, to the modern-day. In the primitive period, community development aimed at protecting communities from enemies or other cities. The highest priority then was to establish a robust defense strategy for community protection. Customs, traditions, and taboos were the guiding principles in that era.

In the pre-industrial period, community development transcended into the mobilization of resources. Societies plundered the resources of other communities for their growth, development, and sustainability. The focus of community development during this period was for workforce development and self-defense, and this was achieved by resource mobilization. During the industrial period, community development was seen in a new light. Infrastructural development and resource mobilization for industrial growth were the two driving forces of community development during this period. In the modern-day, community development has witnessed a drastic shift in focus. The social well-being of people is the focus of community growth and development. These activities are spread across all the positive elements required to enhance the social welfare of the individual and society.

The planning and implementation of community development programs involve more people in the modern-day than all other periods. Today, it is more of an interdisciplinary affair, aimed at solving the wicked problem of the society and making judicious use of our scarce resources (United Nations Department of Economic and Social Affairs, 2008). This has become a necessary skill required for effective community growth and development. The required community development burden has become enormous, and efforts made by local organizations and the government to cater to all the ramifications of individual and societal needs are not sufficient. Hence, the need for NGO interventions in addressing these gaps.

The term NGO was first used after World War II by the UN to refer to the private organizations that helped heal the victims of the war who were displaced, and the millions of children who were made orphans. The term NGO encompasses a broad range of organizations, which vary according to their purpose, philosophy, sectorial expertise, and scope of activities.

Study Area:

FCT is the capital city of Nigeria. Located around the middle belt region, it shares its borders with the Niger, Kaduna, Nasarawa, and Kogi states. The FCT lies within latitude $8^{\circ} 25$ and $9^{\circ} 20$ North of the Equator and longitude $6^{\circ} 45$ and $7^{\circ} 39$ East of the Greenwich meridian. These coordinates positions Abuja in the center of Nigeria. The FCT has a landmass of 7,315km². Based on the most recent population projection in 2016, the FCT had a population of 2,679,200.

FCT was created on February $3^{\text {rd }}, 1976$, from parts of the Nasarawa, Niger and Kogi states. Abuja is the Central Business District (CBD) of FCT, and the name Abuja is used interchangeably as both the capital FCT within the nation and the CBD within FCT. Abuja officially became the capital of Nigeria on December 12, 1991, replacing Lagos as the nation's capital. Abuja was chosen as the capital because it is centrally located in Nigeria, thus making it easily accessible by other states. It has a low population density because of the availability of landmass for future expansion and its favorable climate. 
Table 1: Area Councils in the Federal Capital Territory with their respective Headquarters and population densities.

\begin{tabular}{llll}
\hline \hline$\#$ & Area Council & Head Quarters & Population \\
\hline \hline 1 & Abuja Municipal Area Council & Garki & $1,967,500$ \\
\hline 2 & Abaji Area Council & Abaji & 148,600 \\
\hline 3 & Gwagwalada Area Council & Gwagwalada & 402,000 \\
\hline 4 & Kuje Area Council & Kuje & 246,400 \\
\hline 5 & Bwari Area Council & Bwari & 581,100 \\
\hline 6 & Kwali Area Council & Kwali & 218,400 \\
\hline
\end{tabular}

\section{Source: City Population}

A significant monument that brands Abuja is Aso-rock, a 400-meter monolith left by a series of water erosions. Another monument of the city is the Zuma rock, situated West of Abuja with an elevation of $1125 \mathrm{~m}$. The Zuma rock is very famous for having natural contours which project the face of a human with visible eyes, nose, and mouth. Owing to its location, the FCT is classified under the moderate climatic zone as it is situated in the savannah region. As a result, the FCT experiences three seasons every year; a warm, humid rainy season; a blistering dry season; and a brief harmattan in between which is a result of the northeast trade wind. Minerals found in abundance in this region are marble, tin, mica, clay, wolframite, tantalite, and talc.

Six administrative units divide the FCT. These units are also known as area councils and are the equivalent of local government areas in other states; thus, they are headed by a chair (see Table 1). These chairs are elected the same way local government chairs are elected in other states in the country.

\section{Federal Capital Territory, Nigeria}

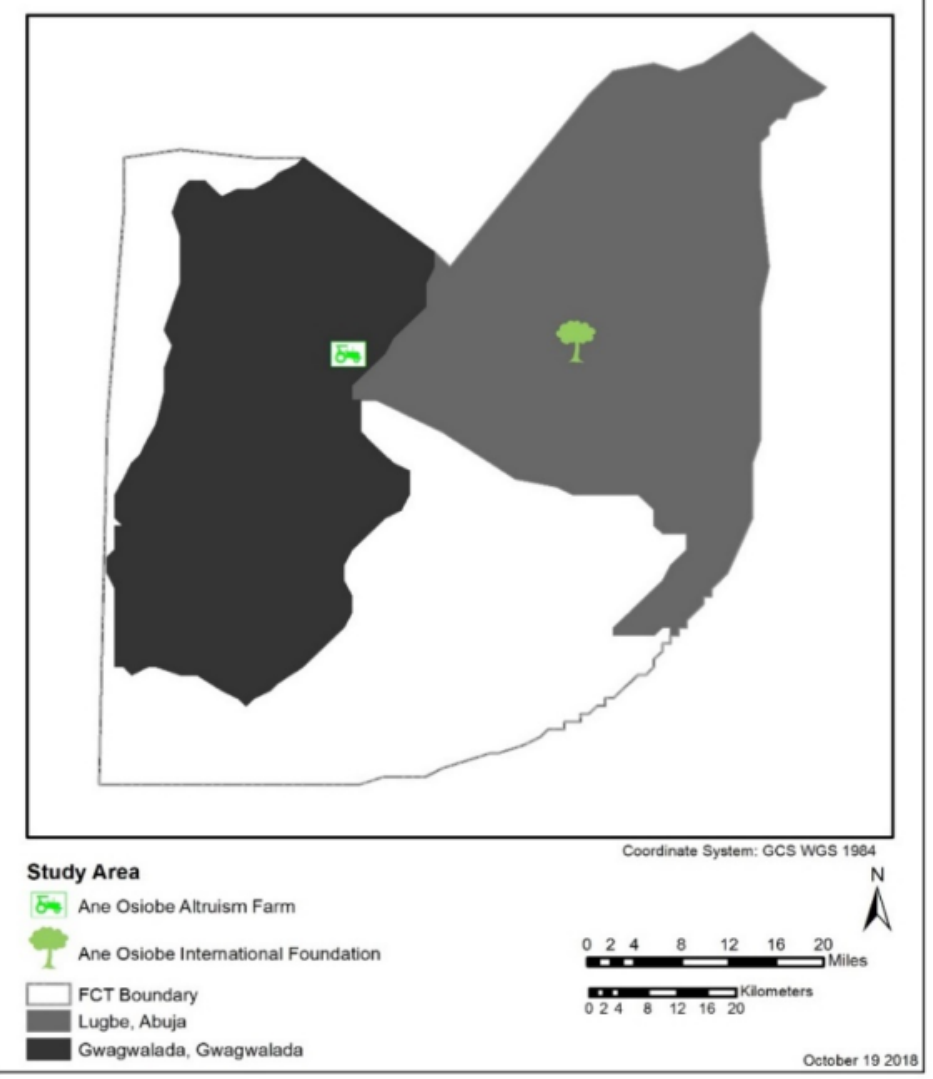

Figure 1: Map of the FCT, Nigeria 


\section{NGOs and Rural Development:}

There are 364 NGOs in the FCT area alone that are recognized by the Nigerian Network of NGOs carrying out various forms of programs and projects in Abuja. Even though these NGOs differ in their focus, they are united by the same purpose, which is to improve the socio-economic condition of people in FCT. Some of the various facets of community development that are of interest for these NGOs include but are not limited to anti-corruption, war against human trafficking, children's rights advocacy, girls' education advocacy, economic empowerment, rural infrastructure development, community health, education for all, women empowerment, and capacity building. This study will analyze how donations flow into NGOs for them to carry out their set goals and objectives.

\section{Methodology:}

Developed in 1956 from the Massachusetts Institute of Technology (MIT), the System Dynamics (SD) model is a methodology used to simulate the dynamic movement of a scenario. The SD field grew out of cybernetics, control theory, and cognate research into nonlinear dynamics. The SD idea originated in physics, mathematics, and engineering (Forrester, 1968, 1973; Sterman, 2002). The equations for the overall model are in the Appendix, while Table 2 shows the work breakdown structure and the Simulation Parameters of the stocks, flows, and variables in the $N G O_{D}-D E M$.

\subsection{Data:}

The data used for the $N G O_{D}-D E M$ (Figure 2), was generated from the information in Table 2.

Table 2: Simulation Parameters, Data, and Sources

\begin{tabular}{|c|c|c|c|c|c|c|}
\hline Variables & Parameter & $\begin{array}{l}\text { Most Recent } \\
\text { Value }\end{array}$ & Sources & URL/Meaning & $\begin{array}{l}\text { Most } \\
\text { Recent } \\
\text { Year }\end{array}$ & $\begin{array}{l}\text { Last } \\
\text { Updated }\end{array}$ \\
\hline Growth Rate & $P O P_{R}$ & 2.6 & $W D I$ & $\begin{array}{l}\text { https://data.worldbank.org/indicato } \\
\text { r/SP.POP.GROW?locations }=N G\end{array}$ & 2017 & 2019 \\
\hline Population & $P O P$ & $190 M$ & $W D I$ & $\begin{array}{l}\frac{\text { https://data.worldbank.org/indicato }}{\text { r/SP.POP.TOTL?locations }=N G} \\
\end{array}$ & 2017 & 2019 \\
\hline $\begin{array}{l}\text { Population } \\
\text { Growth }\end{array}$ & $P O P_{g}$ & \multicolumn{5}{|c|}{$P O P_{R} * P O P$} \\
\hline $\begin{array}{l}\text { Labor Market } \\
\text { Participation }\end{array}$ & $L M_{P}$ & $55.21 \%$ & $W D I$ & $\begin{array}{l}\text { https://data.worldbank.org/indicato } \\
\text { r/SL.TLF.ACTI.ZS? locations }=N G\end{array}$ & 2018 & 2019 \\
\hline$G D P$ & $G D P$ & $\$ 375 B$ & $W D I$ & $\begin{array}{l}\underline{\text { https://data.worldbank.org/indicato }} \\
\underline{r / N Y \cdot G D P . M K T P . C D ? \text { locations }=N} \\
\underline{G}\end{array}$ & 2017 & 2019 \\
\hline \multirow[t]{2}{*}{ Capital Stock } & $\mathrm{CO}$ & $\$ 1.87 T$ & FRED & $\begin{array}{l}\text { https://fred.stlouisfed.org/series/RK } \\
\underline{\text { NANPNGA666NRUG }}\end{array}$ & 2014 & May 2018 \\
\hline & LO & $\begin{array}{l}1.90886 e \\
+08\end{array}$ & $W D I$ & $\begin{array}{l}\text { https://data.worldbank.org/indicato } \\
\text { r/SP.POP.TOTL?locations }=N G\end{array}$ & 2017 & 2019 \\
\hline $\begin{array}{l}\text { Foreign Direct } \\
\text { Investment }\end{array}$ & $F D I$ & & & $\max \left(\gamma *\left(L_{R K}-F D I\right), 0\right)$ & & \\
\hline Investment & $I$ & $Y * S_{R}$ & & & & \\
\hline Labor & $L$ & & & $P O P * L M_{P}$ & & \\
\hline $\begin{array}{l}\text { Local Return on } \\
\text { Capital }\end{array}$ & $L_{R K}$ & & & $A *(1-a) *\left(L^{a}\right) *\left(K^{-a}\right)$ & & \\
\hline Depreciation & $\delta$ & $10 \%$ & $\begin{array}{l}\text { T. Piketty, } \\
2014\end{array}$ & Capital in the Twenty-First Century & N/A & N/A \\
\hline Depreciation Rate & $\delta_{R}$ & $10 \%$ & $\begin{array}{l}\text { T. Piketty, } \\
2014\end{array}$ & Capital in the Twenty-First Century & $N / A$ & $N / A$ \\
\hline $\begin{array}{l}\text { Foreign Return on } \\
\text { Capital (Risk-free } \\
\text { investment) }\end{array}$ & $R_{F I}$ & 2.53 (monthly) & FRED & $\begin{array}{l}\text { https://fred.stlouisfed.org/series/GS } \\
\underline{10}\end{array}$ & 2019 & May 2019 \\
\hline $\begin{array}{l}\text { Cobb-Douglas } \\
\text { Parameter }\end{array}$ & $A L^{a} K^{1-a}$ & $\begin{array}{c}a=.2 \\
A=9.46\end{array}$ & $\begin{array}{l}\text { Adetunji et } \\
\text { al. (2012) }\end{array}$ & $\begin{array}{l}\text { On Restricted Least Squares: The } \\
\text { Cobb-Douglas Production Function } \\
\text { for the Nigerian Economy }\end{array}$ & $N / A$ & $N / A$ \\
\hline
\end{tabular}




\begin{tabular}{|c|c|c|c|c|c|c|}
\hline Alpha & $\alpha$ & & & & & \\
\hline Savings Rate & $S_{R}$ & $18.2 \%$ & $W D I$ & 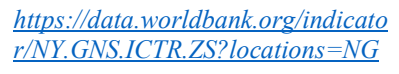 & 2017 & 2019 \\
\hline $\begin{array}{l}\text { Income Threshold } \\
\text { to Donate }\end{array}$ & $Y_{\text {donate }}$ & $\begin{array}{l}\text { Anything } \\
\text { greater than } \\
\$ 14,000\end{array}$ & $A_{S A}$ & $A_{S A}$ & $N / A$ & $N / A$ \\
\hline Lambda & $\lambda$ & $A_{S A}$ & $A_{S A}$ & $\begin{array}{l}\text { The responsiveness of NGOs } \\
\text { donations to the difference between } \\
\text { the Nigerian income threshold and } \\
\text { per capita income at time }(t)\end{array}$ & $N / A$ & $N / A$ \\
\hline Capital & $K$ & & & teg $\left(F D I+I+N G O_{\text {Donation }}-\delta, C\right.$ & & \\
\hline Sigma & $\Sigma$ & $A_{S A}$ & $A_{S A}$ & $\begin{array}{l}\text { The responsiveness of investment to } \\
\text { the rate of foreign retune on capital } \\
\text { to local retune on capital at time }(t)\end{array}$ & $N / A$ & $N / A$ \\
\hline Income Per Capita & $Y_{\text {per-cap }}$ & & & $Y / P O P$ & & \\
\hline Output & $Y$ & & & $A *\left(L^{a}\right) *\left(K^{1-a}\right)$ & & \\
\hline Gamma & $\gamma$ & $A_{S A}$ & $A_{S A}$ & $\begin{array}{l}\text { The responsiveness of FDI retunes } \\
\text { to local retunes on capital at time }(t)\end{array}$ & $N / A$ & $N / A$ \\
\hline$N G O-$ Donations & $N G O_{\text {Donation }}$ & & $\max (\lambda$ & $\begin{array}{r}\left.\left.Y_{\text {donate }}-Y_{\text {per-cap }}\right), 0\right)+ \text { If then els } \\
<Y_{\text {donate }}, \max \left(\Sigma *\left(R_{F I}\right.\right.\end{array}$ & $\begin{array}{l}\left(Y_{\text {per-cap }}\right. \\
\left.\left.\left.L_{R K}\right), 0\right), 0\right)\end{array}$ & \\
\hline
\end{tabular}

\subsection{System Dynamics Model:}

The $N G O_{D}-D E M$ was built based on the information from Table 2, and three simulations were analyzed to estimate the sensitivity of an individual's per capita income and NGO donations.

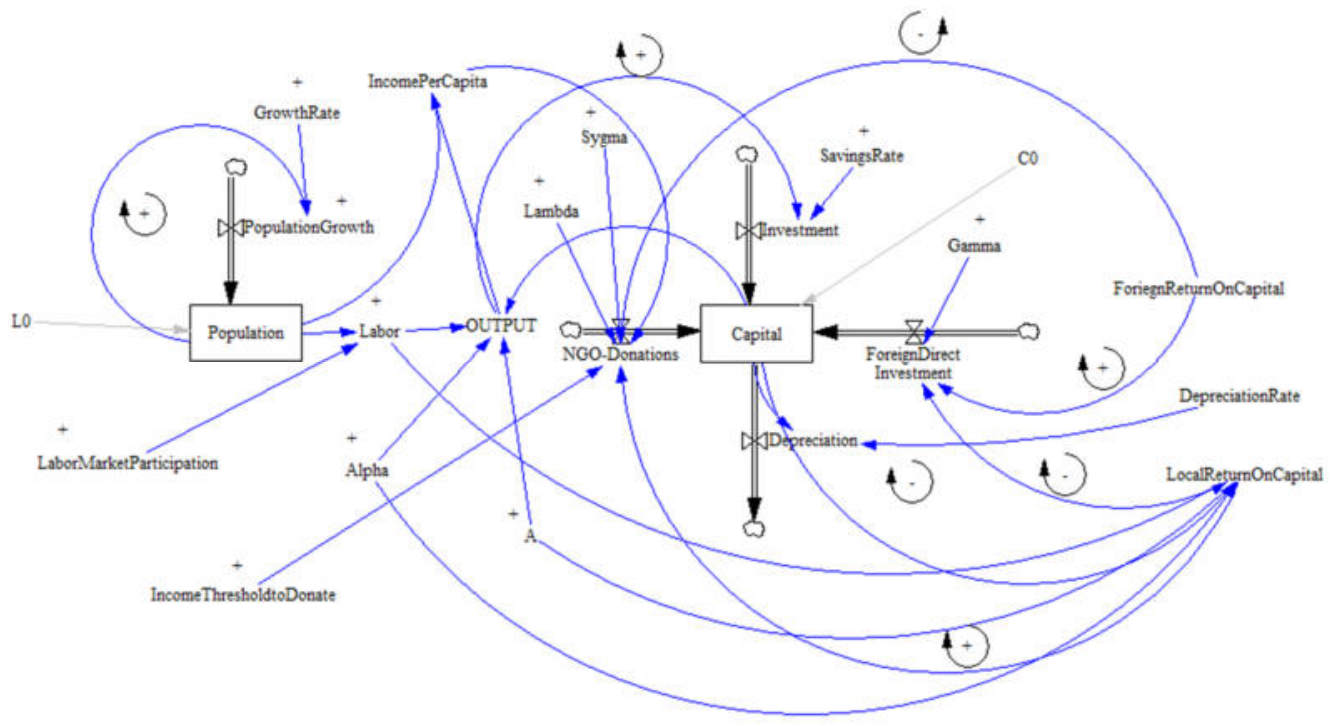

Figure 2: $N G O_{D}-D E M$ 
This methodology is ideal for exploring NGO donations, but one limitation of the study is the lack of data on the NGO industry in the country. The discrepancies between the $Y_{\text {donate }}$ results in stakeholders' variations to donate to the causes of NGOs. This uncertainty includes the $R_{F I}, L_{R K}, S_{R}$, and FDIs into the nation. Our results reveal the sensitivity of $Y_{\text {donate }}$ as it relates to $Y_{\text {per-capita }}$.

3.3 Results:

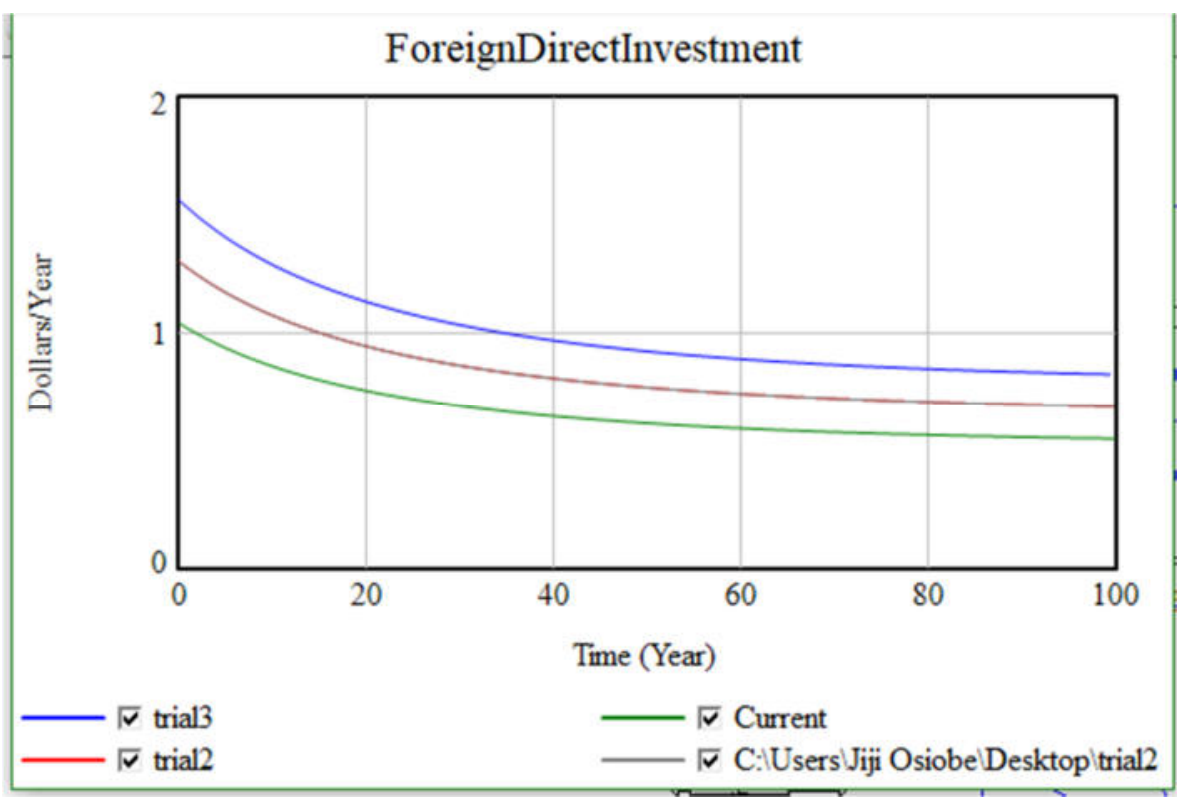

Figure 3: Foreign Direct Investment

The stock and flow diagram of $N G O_{\text {Donation }}$ can be seen in (Figure 2). Figure 3 shows the sensitivity analysis of $F D I$ into the country. The results indicate that if $L_{R K}$ are greater than $R_{F I}$, there would be a high inflow of FDIs into the nation and vice versa. If the later holds to be accurate, then it is more cost-effective for individuals and businesses to donate into the nation than to invest in it. But if the former holds to be true, it would be more profitable for a business or individual to invest in the nation than to donate, as investing would create more jobs and opportunity, increasing the multiplier effect (direct, indirect, and induced effect) of every dollar spent in the nation.

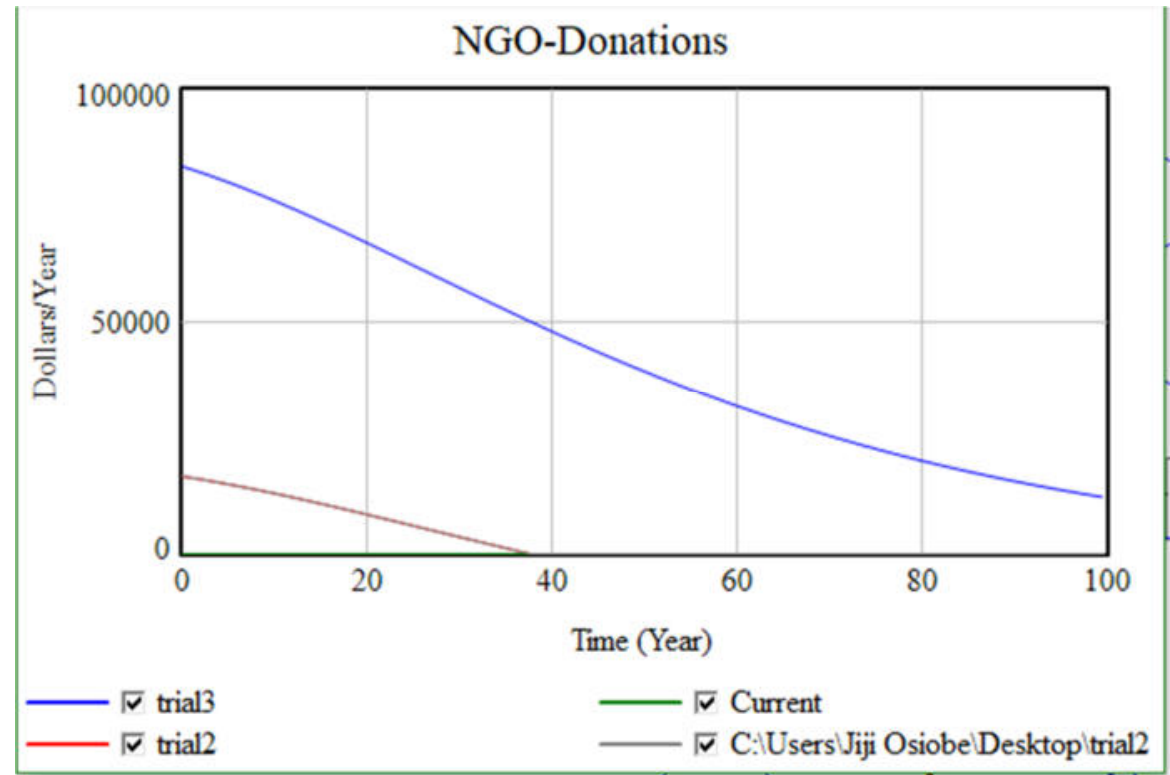

Figure 4: NGO-Donation 
Ceteris-paribus, if the former statement in Figure 2 holds to be true, Figure 4 shows the sensitivity analysis of donations by individuals and businesses in the nation. Hence, there would be zero donations into NGOs if the annual income of an individual or net economic profit made by a corporation is between $\$ 0-\$ 13,000$. But with a yearly salary of $\$ 14,000$ $\$ 80,000$, holding the same figures projections, for companies' net economic profits, donations would increase until it hits a peak; then, it starts to decrease. The diminishing return trend/phenomena in Figure 4 can be explained as an overall boost in the economy revealing that NGOs would be self-sufficient. Hence, residents in the community would not need their services, as the general standard of living in that economy would increase and everyone would be better off. The green line in Figures 3 and 4 show the initial simulation of the $N G O_{D}-D E M$; the red line is the second simulation of the $N G O_{D}-D E M$; and the blue line the is third and final simulation of the $N G O_{D}-D E M$, where the $L_{R K}, S_{R}$, and $Y_{\text {per-capita }}$ were adjected to see how sensitive they are to the $N G O_{D}-D E M$.

\section{Recommendation:}

The UN Sustainable Development Goals (SDGs) are based on the normative ideology that measurements create metrics; metrics create set-targets and set-targets create economic growth and development programs of intervention. The UN SDGs have been successful in creating global awareness on developmental issues around the world. The SDGs have been widely embraced and are now used as the guiding principle for most economic growth, development, and sustainability plans. Despite the acceptance and support for the UN SDGs, which were first the millennium goals by the joint efforts of presidents and prime ministers, public and private sectors, as well as local and international development organizations, over the past years have been somewhat successful. Based on an idea that has been gaining a lot of attention, with little action to support the movement, the following are some recommendations that will foster economic growth, development, and stability in the region:

- The Nigerian government should be more diligent in enforcing the nation's rule of law. This will attract more FDIs into the country and will promote local growth and development.

- The Nigerian government should ensure that property rights laws are effective in protecting foreign investment in properties in Nigeria.

- A diversified economy will attract more FDIs into the economy, hence creating new avenues for people to invest.

- Local return on investments should be more attractive than competing markets around the world. This will spur investors to take a risk, as the rewards will be greater.

- NGOs and other agencies involved with economic growth, development, and stability need to be more proactive in their policies and decision-making strategies rather than being reactive, which has been the norm.

- The partnership between the public, private, and NGOs should have agreed-upon, unified goal(s) where all parties involved are heard, their values are respected in the execution of the project, and particular agenda(s) are met without infringing on anyone's right or harming the environment.

- The NGOs should create and maintain an accurate database to help scholars and researchers study the industry. 5.1 Overarching Findings:

Our results (Figures 3 and 4) illustrate essential principles that will inform policymakers and management in the public, private, and NGO sectors. When the per capita income, net economic profit made by companies, and return on local investment drop, the demand for donations by NGOs will increase as the living standard in the society starts to decrease (not shown in the study).

For the data (Table 2) and $N G O_{D}-D E M$ (Figure 2) structure used, our findings will spark policy debates over a wide range of NGOs programs, donations, funding, and the measures we considered. While the detailed numerical results are valid only for the city of Lugbe, FCT, Nigeria, the approach can be used by other NGOs around the world in creating sustainable economic development plans, projections, and recommendations.

\subsection{Discussion:}

We have confidence that the analytical evidence presented in this work will contribute to informing debates over the best way to handle the ongoing donation challenges that face managerial staff of NGOs and policymakers for controlling the economic burden placed on some NGOs in rural areas. A similar approach as described in this work could be used to discover financial and economically viable measures to address local return on investment as it relates to foreign return on investment. The same approach can also guide local saving rates as it relates to foreign direct investment and domestic direct investment.

\subsection{Takeaways:}

This work has addressed the challenges NGOs face when it comes to donations, for which ongoing debates of why donation keeps decreasing and how can NGOs management persuade the public to increase contributions. It is more defensible to design a donation projection plan with information on the total and marginal inflow and outflow of cash by NGOs, information typically missing in the NGO industry around the world. This work has presented an original approach (with the model in the Appendix) to address widespread gaps of information on how local returns on investment, foreign returns on investment, and income per capita threshold affects donations. While the $N G O_{D}-D E M$ developed and documented investigates much more than donation's pattern in the NGO industry; those donations are the focus of the paper. Our approach can be used to provide valuable information to guide future researchers interested in this topic. 


\subsection{Further Study:}

Although the results of our findings display a positive economic impact on the Nigerian economy if $Y_{\text {donation }}$ is achieved, and the economy shows a steady growth pattern. Further research is necessary for analyzing how $Y_{\text {donate }}$ can be accomplished, while ensuring that: $Y_{\text {per cap }}$ increases $\geq$ to the nation's inflation rate, the $L_{R K}$ is as attractive as other competing countries, $S_{R}$ is at a healthy level, and $I$ continues to grow.

\section{Conclusion:}

It is evident that the issues discussed in this paper are not exhaustive but considering the $N G O_{D}-D E M$ and its subset of factors, the magnitude of the challenges faced by local communities in their pursuit of economic growth, development, and stability is immense. The impact on $L_{R K}, R_{F I}, S_{R}$, and FDIs on the local economic growth, development, and stability process appears to become more pressing. There are circular dilemmas and a cumulative relationship between the stocks, flows, and variables in the $N G O_{D}-D E M$ discussed above in trying to simulate the issues of a regional economy, in some cases resulting in a vicious cycle that requires a clear understanding of the wicked problem in order to generate virtuous cycle sets of factors to interrupt negative outcomes.

This paper utilizes the $N G O_{D}-D E M$ to explore, visualize, and analyze the following dilemmas of NGOs donations responsiveness to Nigeria's per capita income, returns on foreign capital, and the returns on local capital. This paper also analyzed two sensitivity scenarios from the base $N G O_{D}-D E M$ (see Figure 1). The findings show how responsive NGOs activities are in fostering economic growth and development in the community. Our results show that if $L_{R K}$ is greater than $R_{F I}$, there will be a higher inflow of $F D I$ into the nation vice versa. Hence, if the latter statement holds to be true, the costeffectiveness for individuals and businesses to donate or invest in the country will decrease (see Figure 2). But, if the former statement is true, there will be zero donation into NGOs as long as individuals' per capita income is below $Y_{\text {donate }}$ and companies make zero economic profits in their businesses.

The $Y_{\text {donate }}$ is between $\$ 0$ - $\$ 13,000$. But, when the individual per capita income or a business net economic profit is between $\$ 14,000$ - $\$ 80,000$, which is above $Y_{\text {donate }}$, donations and investment will increase until a certain point when it peaks and starts to decrease (see Figure 3). Further result(s) show that the involvements of NGOs in societies where citizens are underserved by the financial, educational, entrepreneurial, political, and health industries had a normal distribution relationship shaped curve for the labor force per capita income threshold, an inverse relationship on returns on $L_{R K}$ and a positive return on $R_{F I}$.

In Nigeria, we need to have a normative standard focusing on the economy's wicked problems and evaluate the threats in our society so we can take advantage of the available opportunities. It is essential to restore consumer confidence for a peaceful and fair environment, where local businesses and individuals can flourish.

\subsection{Declaration of Competing Interest:}

The authors declare that they have no financial interest or personal relationship that could have appeared to directly or indirectly influence the work reported in this paper.

\subsection{Acknowledgment:}

This material is based in part on work that is supported by the Ane Osiobe Trendsetters series department under the Ane Osiobe International Foundation. As specified under the ethics statement of the Ane Osiobe International Foundation, the Ane Osiobe Trendsetters series is dedicated to providing the public with transparent, unbiased information to help foster growth and development in Nigeria and Africa.

\section{References}

Binder-Aviles, H. (2012). The NGO Handbook (The Handbook Series Edition ed.). United States of America: Bureau of International Information Programs, United States Department of State. Retrieved May 12, 2019

Chattopadhyay, S. (2014, August 4). The World Bank. Retrieved from Redefining the Roles of NGOs: http://blogs.worldbank.org/publicsphere/redefining-roles-ngos

City Population. (2017, November 7). Federal Capital Territory, Nigeria. Retrieved from City Population:

Etuk, I. O. (2014, May-June). The Role of Non-Governmental Organizations In Participatory and Sustainable Rural Economic Development in Nigeria. IOSR Journal of Economics and Finance, IV(1), 22-30. Retrieved April 28, 2019, from www.iosrjournals.org

Forrester, J. (1973). Confidence in models of Social Behavior with Emphasis on System Dynamics Model. System Dynamics Group Working Paper.

Forrester, J. W. (1968). Industrial Dynamics.

Forrester, J. W. (1989). The Begining of System Dynamics. 
Grantspace. (2015, May 11). What is an NGO? What role does it play in civil society? Retrieved April 28, 2019, from Grantspace: https://grantspace.org/resources/knowledge-base/ngo-definition-and-role/

Launi, S. (2016). Zaria, Kaduna, Nigeria: A.B.U Zaria.

Launi, S. (2016, February). Assessing The Contribution of Non-Governmental Organizations in Human Development in Bauchi and Gombe States, Nigeria. Zaria, Kaduna, Nigeria: Kubanni.

Launi, S. (2016). Assessing the Contribution of Non-Governmental Organizations on Human Developments in Bauchi and Gombe States, Nigeria. Zaria: A.B.U Press.

Launi, S. (2016). Assessing the Contribution of Non-Governmental Organizations on Human Developments in Bauchi and Gombe States, Nigeria. Zaria: A.B.U Press.

Law Nigeria. (2011, November 29). Federal Capital Territory. Retrieved from Law Nigeria: http://lawnigeria.com/Abuja/Abuja.html

Louisiana Community Network. (2008). Introduction to Community Development. Louisiana: Louisiana Community Network.

New World Encyclopedia. (2019, January 29). Abuja. Retrieved from New World Encyclopedia: https://www.newworldencyclopedia.org/entry/Abuja

Omofonmwan, S. I., \& Odia, L. (2009). The Role of Non-Governmental Organisations in Community Development: Focus on Edo State-Nigeria. The Anthropologist, XI(4), 247-245. Retrieved April 28, 2019

State Resource Centre Kerala. (2015). Community Development. Kerala: Commonwealth of Learning.

The United Nations Department of Economic and Social Affairs. (2008). Achieving Sustainable Development and Promoting Development Cooperation. New York, NY: United Nations Publications. 


\section{Appendix:}
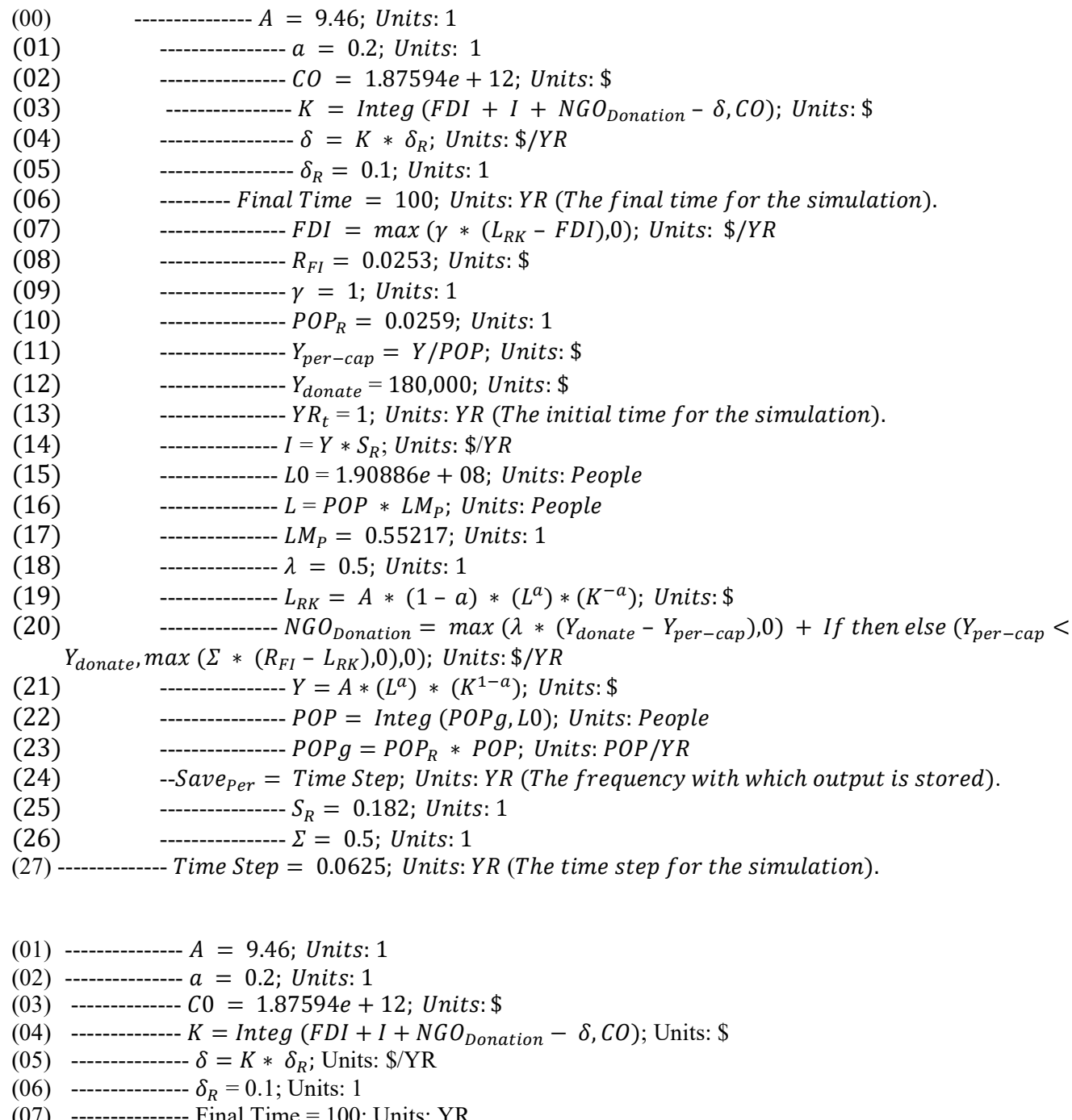

The Final time for the Simulation.

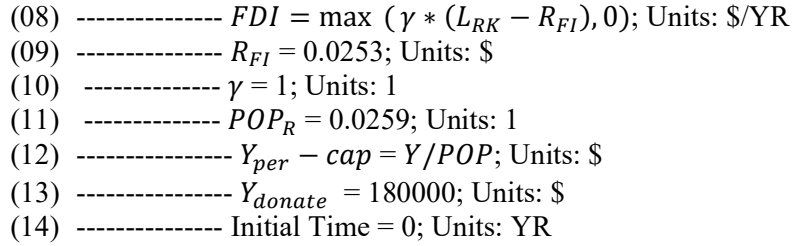

The Initial time for the Simulation.

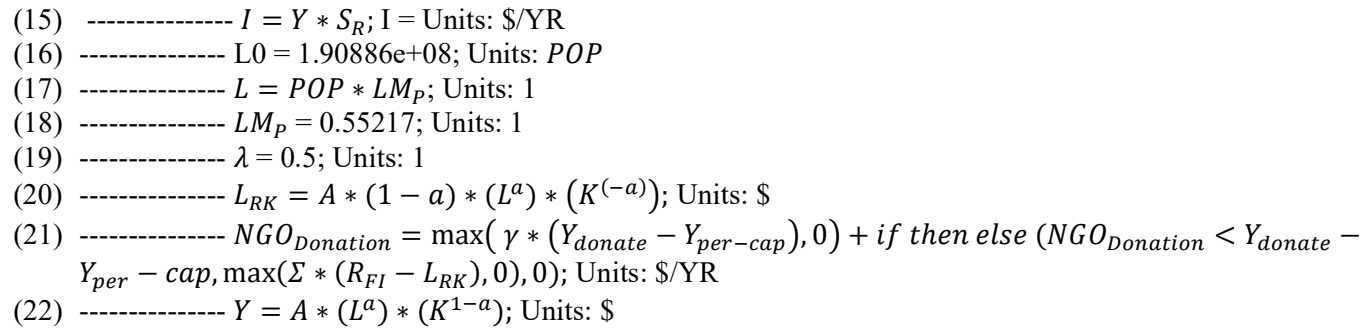


(23) ---------- $P O P=$ Integ $\left(P O P_{g}, L O\right)$; Units: $P O P$

(24) --------- $P O P_{G}=P O P_{R} * P O P$; Units: $P O P / Y R$

(25) ---------- $S_{R}=$ TIMESTEP; Units: YR

The Frequency with which output is Stored.

(26) ------------ $S_{R}=0.182$; Units: 1

(27) ---------- $\Sigma=0.5$; Units: 1

(28) ------------ TIMESTEP $=0.0625$; Units: YR 